\title{
Removal of chromate from tannery wastewater: the applicability of sulfate-green rust in real coprecipitation processes
}

\author{
Abdullah Al MAMUN ${ }^{1}$, Myint Myint KHIN ${ }^{1}$, Giuseppe GRANATA ${ }^{2}$ \\ and Chiharu TOKORO ${ }^{2 *}$ \\ ${ }^{1}$ Graduate School of Creative Science and Engineering, Waseda University, 3-4-1 Okubo, Shinjuku-ku, Tokyo
169-8555, Japan
${ }^{2}$ Faculty of Science and Engineering, Waseda University, 3-4-1 Okubo, Shinjuku-ku, Tokyo 169-8555, Japan
}

\begin{abstract}
Ferrihydrite and green rust (GR) have been identified as promising removing agents for chromate. However, while ferrihydrite efficiency is the still too low for practical applications, it is not known whether GR is stable in real wastewater systems. In this work, we investigated the removal of chromate from a real tannery wastewater by using sulfate-GR and ferrihydrite. We studied the effect of $\mathrm{pH}$ and $\mathrm{Cr} / \mathrm{Fe}$ molar ratios on removal performances and elucidated the removal mechanism by XRD analysis. We performed removal experiments from simple chromate-bearing solutions under non-oxidizing Ar atmosphere, and from complex solution under open air atmosphere.
\end{abstract}

Key words: Chromate, Green rust, Wastewater treatment, Tannery

\section{Introduction}

Hexavalent chromium ( $\mathrm{Cr}(\mathrm{VI}))$ is well-known for being carcinogenic and difficult-to-remove from water due to its high mobility ${ }^{1}$. For this reason, the improper discharge of chromate is a major concern, especially for industrial processes such as electroplating, tannery and production of painting pigments ${ }^{2}$.

The conventional practice in $\mathrm{Cr}(\mathrm{VI})$ removal is based on adsorption and/or ion exchange on cationic resins. However, the non-satisfactory efficiency at low $\mathrm{Cr}(\mathrm{VI})$ concentration and the lack of sustainability require for the development of alternative methods. Most of sites identified for $\mathrm{Cr}(\mathrm{VI})$ pollution are in fact located in developing countries $^{3}$, where high costs for wastewater treatment cannot be sustained. More sustainable removing agents were recently obtained from agricultural waste ${ }^{5}$. Nevertheless, despite the lower cost, these materials are often geographically localized and seasonal ${ }^{4,5}$.

A promising removing ability for $\mathrm{Cr}(\mathrm{VI})$ has been recently identified in iron oxides species

Accepted 1 June, 2018

*e-mail: tokoro@waseda.jp like ferrihydrite and green rust ${ }^{6,7}$. Ferrihydrite $\left[\left(\mathrm{Fe}^{\mathrm{III}}\right)_{2} \mathrm{O}_{3} \cdot 0.5 \mathrm{H}_{2} \mathrm{O}\right]$ is a hydrous ferric oxyhydroxide that was found able to immobilize chromate from water via surface complexation. However, its removal efficiency seems to be too low for commercial applications and a large production of sludge has to be expected upon chromate removal $^{8}$. Green rust (GR) is a mixed Fe(II)-Fe(III) hydroxide that can be described by the formula $\left[\mathrm{Fe}(\mathrm{II})_{(6-\mathrm{x})} \mathrm{Fe}(\mathrm{III})_{\mathrm{x}}(\mathrm{OH})_{12}\right]^{\mathrm{x}+}\left[(\mathrm{A})_{\mathrm{x} / \mathrm{n}} \cdot \mathrm{yH}_{2} \mathrm{O}\right]^{\mathrm{x}-}$, where $A$ is the anion and $n$ is the anion charge. GR exhibits a layered double hydroxide (LDH) structure where Fe hydroxide units are intercalated with water molecules and anions such as chloride, carbonate and sulfate ${ }^{9}$. Given the high $\mathrm{Fe}(\mathrm{II}) / \mathrm{T}-\mathrm{Fe}$ ratio, ranging between 0.66 and $0.75^{10,11}$, GR has a considerable reducing power towards potential oxidized contaminants such as chromate, arsenate and organic molecules ${ }^{12}$.

Although GR has been proven more efficient than ferrihydrite, all studies were performed in controlled $\mathrm{Ar} / \mathrm{N}_{2}$ atmosphere and from simple synthetic solutions containing only the targeted contaminant. It is not known whether GR would retain its efficiency in complex wastewater systems and under open air atmosphere. As a matter of fact, due to the large portions of $\mathrm{Fe}(\mathrm{II})$, 
GR might be oxidized before reducing chromate and lose its efficiency.

In this work, we studied the removal of chromate from a tannery wastewater produced at the Bangladesh Small and Cottage Industry Corporation (BSCIC) tannery industrial estate in Bangladesh. The tannery wastewater is a very complex media as processing 1 ton of raw hides requires more than $450 \mathrm{~kg}$ of different chemicals and results into $40-70 \mathrm{~m}^{3}$ of wastewater. This wastewater is later discharged with all its pollution load in nearby water bodies, threatening the ecosystem and the human health.

In the present research, the removal of chromate was studied by using sulfate-GR and ferrihydrite. We investigated the effect of $\mathrm{pH}$ and $\mathrm{Cr} / \mathrm{Fe}$ molar ratio and elucidated the removal mechanism by assisting the removal experiments with XRD analysis. In order to confirm the applicability of GR in real processes, we performed removal experiments from simple chromate-bearing solutions under non-oxidizing Ar atmosphere, and from complex solution under open air atmosphere.

\section{Experimental}

\subsection{Site description}

The Bangladesh Small and Cottage Industry Corporation (BSCIC) is a tannery industrial estate in Savar, Dhaka (Bangladesh) comprised with 220 from medium to large category tanneries. BSCIC is the biggest tannery estate in Bangladesh and it is located beside the Dhaleshwari River (Fig. 1). The wastewater produced by all tanneries are collected and treated at the central effluent treatment plant (CETP) prior to discharging in the Dhaleshwari River. To prevent pollution of the nearby area, a constant monitoring activity is performed by sampling and analysis of the water outflowing from the CETP. The main physical
Table 1 Quality of the effluent discharged at the BSCIC tannery industrial estate, Savar, Dhaka, Bangladesh

\begin{tabular}{ccccc}
\hline $\mathrm{pH}(-)$ & $\begin{array}{c}\mathrm{DO} * \\
(\mathrm{mg} / \mathrm{L})\end{array}$ & $\begin{array}{c}\mathrm{BOD} 5 * * \\
(\mathrm{mg} / \mathrm{L})\end{array}$ & $\begin{array}{c}\mathrm{COD} * * * \\
(\mathrm{mg} / \mathrm{L})\end{array}$ & $\begin{array}{c}\text { Total Cr } \\
(\mathrm{mg} / \mathrm{L})\end{array}$ \\
\hline $8.1-8.25$ & $0-0.2$ & $100-350$ & $250-1000$ & $10-15$ \\
\hline
\end{tabular}

*DO: Dissolved oxygen, **BOD5: Biochemical Oxygen Demand (5 days), ${ }^{* * *}$ COD: Chemical Oxygen Demand

chemical parameters determined from the wastewater flowing out the CETP are shown in Table 1.

\subsection{Standards and reagents}

All chemicals used in this study were analytical grade reagents from Wako Chemical Industries (Japan). The $\mathrm{Cr}(\mathrm{VI})$ solution was prepared by dissolving $\mathrm{K}_{2} \mathrm{CrO}_{4}$ in deionized water. GR was produced by mixing stock solutions of $\mathrm{FeSO}_{4} \cdot 7 \mathrm{H}_{2} \mathrm{O}$ and $\mathrm{Fe}_{2}\left(\mathrm{SO}_{4}\right)_{3} \cdot \mathrm{nH}_{2} \mathrm{O}$ while ferrihydrite was prepared by dissolving $\mathrm{Fe}\left(\mathrm{NO}_{3}\right)_{3} \cdot 9 \mathrm{H}_{2} \mathrm{O}$ in water. When investigating the use of GR and ferrihydrite from simple Cr-bearing solutions under Ar atmosphere, all experiments were carried out in a gas displacement type acrylic glove box equipped with pass box and oxygen meter (As-One, Japan). When investigating the use of GR from a complex $\mathrm{Cr}$ media under air atmosphere, experiments were performed without using any glove box.

The tannery wastewater used in this study was a synthetic solution prepared based on material flow (Fig. 2) and characterization data (Table 2). Since the COD in the wastewater is mostly due to the release of the skin fat during the process, the synthetic solutions was prepared by dissolving fatty acids in water according to the composition shown in Table 3. Accordingly, the DO of the solution was initially fixed to less than $0.1 \mathrm{mg} / \mathrm{L}$ by bubbling Ar gas before starting the experiments. The COD was measured using the standard titration method ${ }^{13}$. In order to confirm the GR formation, $\mathrm{pH}$ and ORP were continuously recorded

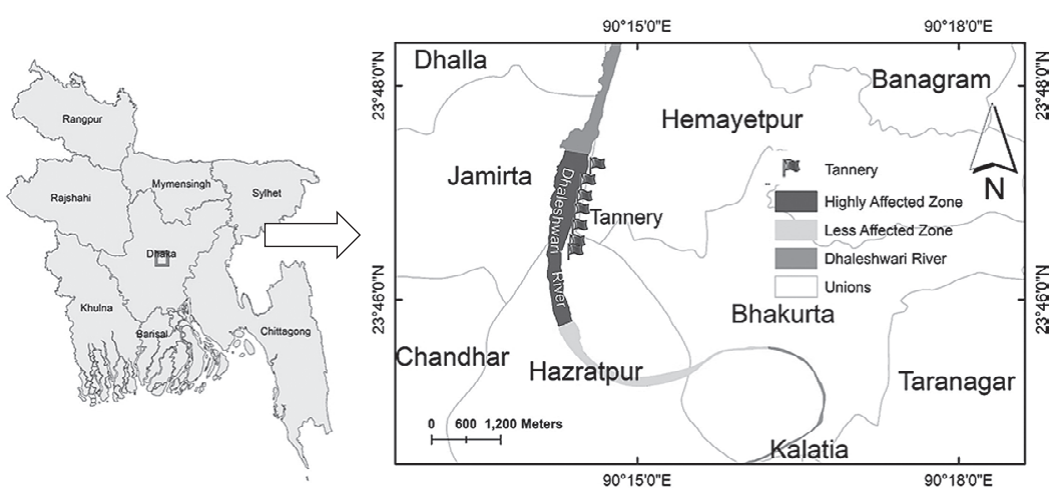

Fig. 1 Area affected by Cr pollution near the Dhaleswari River, Dhaka, Bangladesh. 
Removal of chromate from tannery wastewater: the applicability of sulfate-green rust in real coprecipitation processes

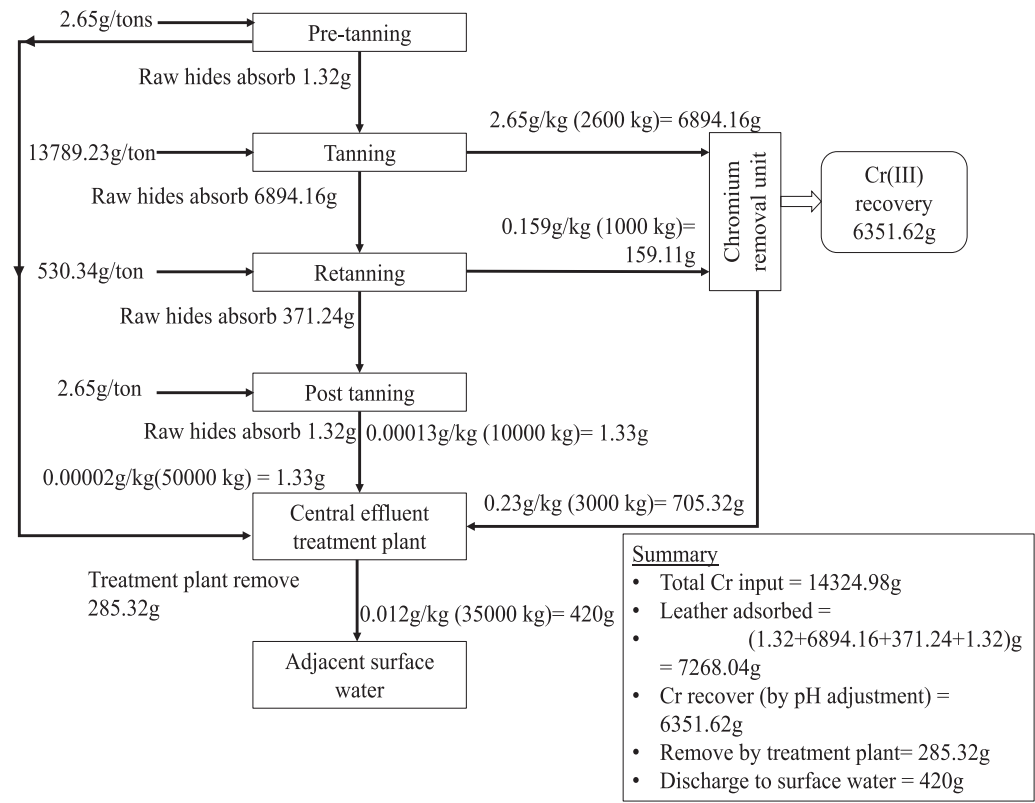

Fig. 2 Flow chart of tannery process and Cr mass balances for 1 ton of raw hides.

Table 2 Chemical load for 1 ton raw hides processing (Data from Samina tannery Pvt. Ltd, Dhaka, Bangladesh)

\begin{tabular}{|c|c|c|c|c|}
\hline Process name & $\begin{array}{c}\text { Chemicals name \& } \\
\text { Chemical inputs }(\mathrm{kg} / \mathrm{t})\end{array}$ & $\begin{array}{l}\text { Wastewater discharged } \\
(\mathrm{kg} / \mathrm{t})\end{array}$ & $\begin{array}{l}\text { Total discharged } \\
(\mathrm{kg} / \mathrm{t})\end{array}$ & $\begin{array}{c}\text { Sectoral average } \\
(\%)\end{array}$ \\
\hline Soaking & $\begin{array}{l}\text { Degreasing agents }=3 \\
\text { Soda ash }=10 \\
\text { Antibacteria }=2\end{array}$ & 18400 & & 43.4 \\
\hline Liming & $\begin{array}{l}\text { Sodium sulfide }=40 \\
\text { Lime }=40 \\
\text { Degreasing agent }=2\end{array}$ & 9600 & & 22.7 \\
\hline Deliming & Ammonium sulfate $=26$ & 2080 & & 4.9 \\
\hline Batting & Batting enzyme $=6.5$ & 10400 & & 24 \\
\hline Tanning & $\begin{array}{l}\text { Sodium chlorite }=5.2 \\
\text { Cr(III) sulfate }=104 \\
\text { Formic acid }=13 \\
\text { Hypo }=10.4 \\
\text { Sodium formate }=13 \\
\text { Fungicide }=2.6 \\
\text { Magnesium oxide }=13\end{array}$ & 1300 & 42380 & 3.1 \\
\hline Retanning & $\begin{array}{l}\text { Formic acid }=0.6 \\
\text { Cr(III) sulfate }=6 \\
\text { Neutralizing syntans }=6 \\
\text { Aldehyde }=4\end{array}$ & 400 & & 0.8 \\
\hline $\begin{array}{l}\text { Dyeing and } \\
\text { fat liquoring }\end{array}$ & $\begin{array}{l}\text { Synthetic fat liquor }=2 \\
\text { Acrylic resin }=10 \\
\text { Other synthetic resin }=20 \\
\text { Syntans }=10 \\
\text { Vegetable extract }=20 \\
\text { Fat liquor }=10-20 \\
\text { Formic acid }=4-8\end{array}$ & 200 & & 0.4 \\
\hline
\end{tabular}

during the experiments using $\mathrm{pH}$ meter (Thermo Scientific) and ORP meter (Horiba Scientific).

\subsection{Batch test and analysis}

The coprecipitation of ferrihydrite with $\mathrm{Cr}(\mathrm{VI})^{14-17}$ was investigated for different $\mathrm{Cr} / \mathrm{Fe}$ 
Table 3 Synthetic wastewater composition

$\begin{array}{lr}\text { Lauric acid }(\mathrm{mg} / \mathrm{L}) & 34.5 \\ \text { Formic acid }(\mathrm{mL} / \mathrm{L}) & 2.0 \\ \text { Sodium thiosulfate }(\mathrm{mg} / \mathrm{L}) & 20.0 \\ \text { Formaldehyde }(\mathrm{mL} / \mathrm{L}) & 3.0 \\ \text { Sodium sulphide }(\mathrm{mg} / \mathrm{L}) & 11.6 \\ \text { Sodium chloride }(\mathrm{mg} / \mathrm{L}) & 60.0 \\ \text { Cr(VI) }(\mathrm{mg} / \mathrm{L}) & 10.0\end{array}$

molar ratio. In the experiments with GR, the $\mathrm{Fe}(\mathrm{II}) / \mathrm{Fe}$ (III) ratio was set as 2 and used as total $\mathrm{Fe}$ input. The $\mathrm{pH}$ was continuously monitored during the experiments and adjusted to 5,7 or 9 $( \pm 0.05)$ by adding $0.1 \mathrm{M} \mathrm{HNO}_{3}$ and $0.1 \mathrm{M} \mathrm{KOH}$. After 1 hour under stirring, the suspensions were filtered by using a $0.1-\mu \mathrm{m}$ membrane filter. The filtrates were analyzed by inductively coupled plasma-atomic emission spectrometry (ICP-AES) using an SPS-7800 atomic emission spectrometer (Seiko Instruments Inc., Chiba, Japan). The solid residues were analyzed by $\mathrm{x}$-rays diffraction (XRD) to determine phase composition and crystal structure upon chromate removal. The x-ray diffractometer (Geiger flex RAD-IX, Rigaku Corp. Japan) was equipped with a copper target $(\mathrm{Cu}-\mathrm{K} \alpha)$, a crystal graphite monochromator and a scintillation detector. The X-ray source was operated at $40 \mathrm{kV}$ and $30 \mathrm{~mA}$ with step scanning from $2 \theta$ values of 2 to $80^{\circ}$, sequential increments of $0.02^{\circ}$ and a scan speed of $2 \% \mathrm{~min}$. To avoid the oxidation of samples between experiments and analysis, the collected paste samples were mixed with glycerol and transferred to the XRD chamber ${ }^{18}$. A crystal sample holder was used and the derived pattern was not corrected for background diffraction.

\section{Results and Discussion}

\subsection{Pollution load and Cr-material flow analy- sis in tannery}

The tannery process consists of a complex sequence of operations. The main operations in the process are soaking (preliminary washing to rehydrate the skins and remove dirt and excess of salt), liming (removal of hair and fat), deliming (removal of excess of lime used on liming), batting (softening through enzyme baths), tanningretanning (absorption of chromium into the skins), dyeing and fat liquoring (coloring and fixing the texture), each of them contributing to the overall release of chemicals into wastewater. The sectoral pollution load (Table 2 ) shows that soaking generates about $44 \%$ of the total wastewater volume, whereas more than $70 \%$ of total COD is generated through liming and deliming. The COD generated in these two operations arises from the fat released in water. The chromium release in water is almost entirely due to tanning and re-tanning operations, where $15 \mathrm{~kg}$ of $\mathrm{Cr}$ (III) are used per each tons of raw hides. About $50-70 \%$ of the $\mathrm{Cr}$ (III) used in tanning and re-tanning is absorbed by the hides while remaining part is discharged in water. The Cr-bearing wastewater from tanning and retanning is sent to a chromium recovery section, where $90 \%$ of $\mathrm{Cr}(\mathrm{III})$ is precipitated at $\mathrm{pH}$ to 7.5 8 by dosing $\mathrm{NaOH}$. In contrast, the wastewater generated in pre-tanning and post-tanning is sent directly to the CTEP with liquid stream generated in $\mathrm{Cr}$ (III) recovery because the chromium concentration is too low to be recovered.

Out of the CETP, the concentration of chromium in water is $10-15 \mathrm{mg} / \mathrm{L}$, accounting for a chromium content of about $2.8 \%$ of the total input. The final discharged effluent quality (Table 1) after the CETP also exhibits a low dissolved oxygen (DO $<0.2 \mathrm{mg} / \mathrm{L}$ ), high biochemical oxygen demand at 5 days (BOD5) and high chemical oxygen demand (COD). The COD and BOD5 derive mainly from fatty acids and proteins released in liming and from oxidable inorganic species used within the process. The low DO can be considered as a direct consequence of high COD and BOD5. Indeed, the oxygen naturally-dissolved in water can be consumed by those substances that contribute to COD and BOD5. In this view, since the oxidation of fatty acids and proteins is a relatively slow process, the low DO in the real wastewater can be considered as an expression of long-term pollution. The residual $\mathrm{Cr}$ in the final wastewater is $\mathrm{Cr}(\mathrm{VI})$, which is well-known for remaining soluble even in alkaline media.

Due to the improper discharge of a similar wastewater from the Hazaribag tannery area (Bangladesh), the accumulation of $\mathrm{Cr}(\mathrm{VI})$ was confirmed in the aquatic fauna of the nearby Buriganga River ${ }^{19}$. Given the $20000 \mathrm{~m}^{3}$ of wastewater flowing out of the CETP per day, the adjacent surface water of the Dhaleshwari River is threatened by the continuous discharge of $210 \mathrm{~kg}$ of $\mathrm{Cr}(\mathrm{VI})$ per day.

\subsection{Removal of chromate by coprecipitated ferrihydrite and GR: comparison}

The removal of chromate from water by ferrihydrite and GR was preliminary assessed through coprecipitation experiments from simple $\mathrm{Cr}$ bearing solution under Ar atmosphere. Coprecipitated GR was found to be more effective than ferrihydrite to remove chromate under anaerobic conditions at both pH 5 and 7 (Fig. 3). For GR, increasing $\mathrm{pH}$ from 5 to 7 did not determine any 




Fig. 3 Relationship between Cr(VI) removal with Coprecipitated GR and ferrihydrite at $\mathrm{pH} 5$ and 7 (Aratmosphere).

significant effect on chromate removal. This evidence can be explained considering that $\mathrm{pH}$ can affect chromate removal only indirectly, by determining changes in GR structure. Previous works highlighted that increasing the $\mathrm{pH}$ beyond 8.3-8.5 produces a decrease of surface charge ${ }^{20}$, expansion of GR structure ${ }^{12}$ with increase of surface area and larger inclusion of $\mathrm{Na}^{+}$and $\mathrm{SO}_{4}{ }^{2-}$. As a consequence, more chromate could be removed. However, in this work GR was coprecipitated at pH 5 and 7 for a better comparison with ferrihydrite. Under these conditions, neither structural modifications nor changes of surface charge take place. Thus, changing the coprecipitation $\mathrm{pH}$ of GR from 5 to 7 did not show any significant influence over $\mathrm{Cr}(\mathrm{VI})$ removal.

The higher removal observed for ferrihydriate at $\mathrm{pH} 5$ can be reasonably explained through the higher zeta potential at this $\mathrm{pH}^{6}$. Although ferrihydrite at $\mathrm{pH} 5$ adsorbed chromate completely, $3.96 \mathrm{mmol} / \mathrm{L}$ of $\mathrm{Fe}$ were required to achieve the removal. In contrast, only $0.96 \mathrm{mmol} / \mathrm{L}$ Fe were required to remove the same $0.19 \mathrm{mmol} / \mathrm{L} \mathrm{Cr}$. The 4 times lower amount of iron required with GR is expected to determine a significantly lower production of sludge upon chromate removal.

\subsection{XRD analysis}

The XRD spectra of coprecipitated ferrihydrite upon chromate removal at $\mathrm{pH} 5$ and $\mathrm{pH} 7$ (Fig. 4) highlighted the typical pattern of ferrihydrite (Fh). This evidence suggests that chromate was removed through a kind of adsorption that does not imply any structural change, namely outer-sphere surface complexation. However, for $\mathrm{Cr} / \mathrm{Fe} 0.5$ at $\mathrm{pH}$ 5, the XRD spectra exhibited the broadening of the peak at $34^{\circ}$, resulting in a pattern similar to $\mathrm{Cr}$ inserted ferrihydrite (Cr-Fh). This evidence was previously described as a change of removal mechanism from outer-sphere to inner-sphere surface complexation ${ }^{6}$.

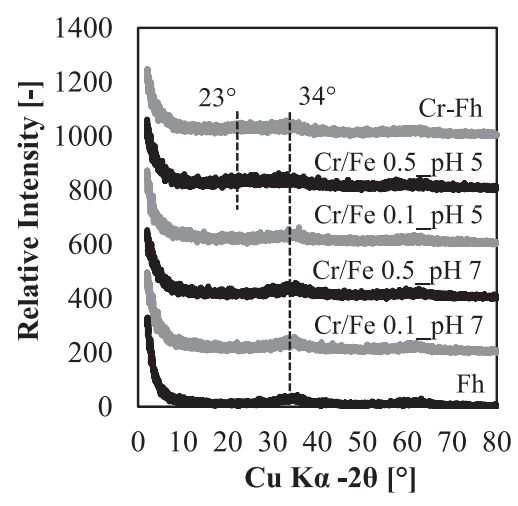

Fig. 4 XRD patterns of solid residue upon chromate removal with Coprecipitated ferrihydrite at $\mathrm{pH} 5$ and 7 (Ar-atmosphere).

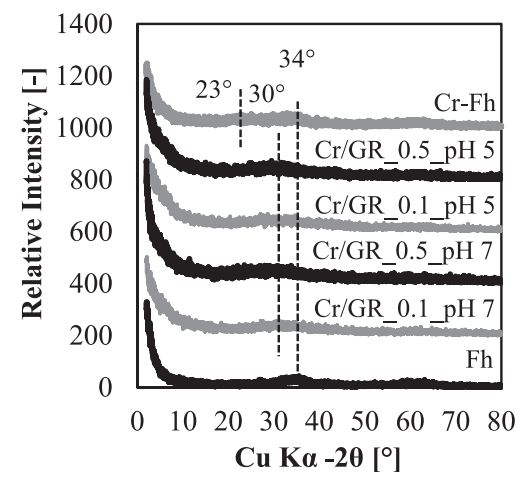

Fig. 5 XRD patterns of solid residue upon chromate removal with Coprecipitated GR at $\mathrm{pH} 5$ and 7 (Ar-atmosphere).

The XRD spectra of GR upon chromate removal at $\mathrm{pH} 5$ and 7 exhibited a new peak at $30^{\circ}$. The new peak, which suggests the oxidation of GR to Cr-inserted ferrihydrite, was observed at both $\mathrm{Cr} /$ Fe molar ration 0.5 and 0.1 (Fig. 5). This evidence suggests that chromium is inserted in the crystal structure already from low $\mathrm{Cr} / \mathrm{Fe}$ ratio, possibly during the formation of GR. In other words, while with ferrihydrite the chromate is included only at high $\mathrm{Cr}$ concentrations, GR co-precipitates directly with chromium.

\subsection{Effect of COD}

By increasing the COD in water, the residual Cr concentration significantly decreased (Fig. 6). To exclude the possibility that chromate was immobilized by some species contributing to COD, we performed control experiments without GR. The residual $\mathrm{Cr}$ concentration in the control experiments was very close to the initial one $(10 \mathrm{mg} / \mathrm{L})$, thus confirming that the immobilization was performed by GR. The larger removal of chromate observed by increasing the COD finds 




Fig. 6 Effect of COD on chromate removal at pH 5, 7 and 9 with fixed $\mathrm{Cr} / \mathrm{GR}(\mathrm{T}-\mathrm{Fe}$ ) ratio 0.5 (Ar-atmosphere).

an explanation in the increased concentration of alkaline cations like $\mathrm{Na}^{+}$. As reported in our previous work, a higher $\mathrm{pH}$ during the GR preparation determines a change of the surface charge from positive to negative ${ }^{20}$, and results into a larger inclusion of $\mathrm{Na}^{+}$(from $\mathrm{NaOH}$ ) within GR structure. As a consequence, GR's structure expands, surface area increases, and more chromate can be removed. In this work, an increase of COD according to the wastewater composition determined also an increase of the concentration of $\mathrm{Na}^{+}$due to oxidable species like sodium sulphide and thiosulfate. Accordingly, a more stable and efficient GR might have generated ${ }^{21}$ and more chromate could be removed.

\section{5. $\mathrm{Cr}(\mathrm{VI})$ removal under open air}

The ability of GR to resist oxidation and immobilize chromate from the complex tannery wastewater under open air atmosphere was verified at $\mathrm{pH} 8.25$, which is the one out of the CETP. The $\mathrm{Eh}(\mathrm{vs} \mathrm{SHE})$ and $\mathrm{pH}$ trends during the formation of GR under open air atmosphere and in the presence of chromate are shown in Fig. 7. The points (a), (b) and (c) in Fig. 7 refer to the photos in Fig. 8, taken during the experiments. The trend shown in Fig. 7 is very similar to the one observed under Ar atmosphere (paper under review). Titrating at $\mathrm{pH} 8.25$ determined a first potential drop from 300 to about $0 \mathrm{mV}$ within 2-4 minutes and a further drop to $-100 \mathrm{mV}$ in the next $10 \mathrm{~min}$ utes. At the same time, the colour of the suspension turned first to light reddish and quickly to light-green (Fig. 8a), thus suggesting the formation of GR. The Eh drop observed within 15 minutes was clearly associated with the decrease of the $\mathrm{Fe}(\mathrm{III}) / \mathrm{Fe}(\mathrm{II})$ ratio for the formation of green rust $^{12}$. Finally, after 25 minutes the experimental Eh gradually increased and the suspension turned reddish-green, thereby suggesting the oxidation of GR to ferrihydrite. The graph in Fig. 7 highlight-

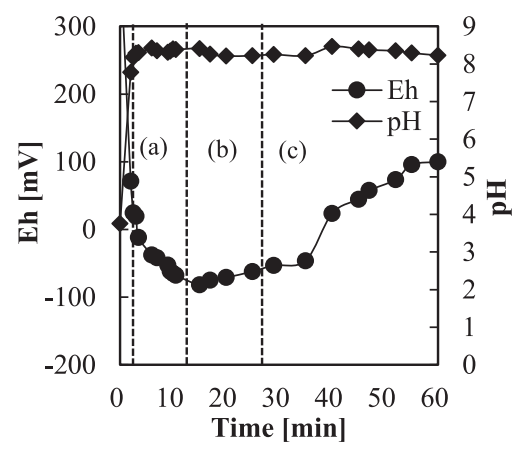

Fig. 7 Eh and $\mathrm{pH}$ during the coprecipitation experiments of synthetic tannery wastewater with GR under open air atmosphere.

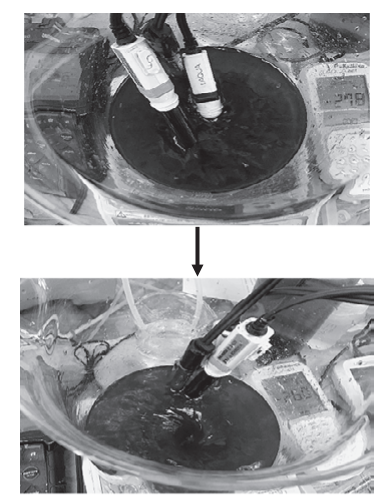

Green rust

(a)



Slightly oxidised

(b)

Moderately oxidised

(b)

Ferrihydrite

(c)

Fig. 8 Colour change during coprecipitation experiments. (a), (b), (c) represent the (a), (b), (c) zones in Fig. 7.

ed slightly higher values of Eh and a change within a shorter period of time compared to the ones reported in literature ${ }^{22}$. This difference can be reasonably considered as the consequence of the partial oxidation of $\mathrm{Fe}^{2+}$ by the oxygen dissolved in solution under open air atmosphere. The ICP analysis revealed a residual concentration of chromium below the detection limit of our ICP, thus 




Fig. 9 XRD of coprecipitated GR with synthetic wastewater under open air atmosphere.

highlighting a complete removal of chromate also under open air.

The final solid product upon chromate removal in the presence of COD and under open air atmosphere was analyzed by XRD. The XRD spectra showed the typical pattern of Cr-inserted ferrihydrite, as suggested by the XRD peak shift from $34^{\circ}$ to $28^{\circ}$ (Fig. 9). In our previous work (currently under review) we proved through XAFS analysis that a close and compact insertion of $\mathrm{Cr}$ was possible only without a significant enlargement of the ferrihydrite structure. As a consequence, the $\mathrm{Cr}-\mathrm{Fe}$ bonding would be stronger and the immobilized $\mathrm{Cr}$ would not be easily released in the environment. The Cr-inserted ferrihydrite found under open air atmosphere suggests a similar consideration. Therefore, the formation of a dense $\mathrm{Cr}$ inserted ferrihydrite sludge with good solid-liquid separability and low chromate release tendency has to be expected also upon coprecipitation from complex systems.

\section{Conclusions}

In this wok we studied the removal of chromate from synthetic tannery wastewater produced at the BSCIC tannery estate in Bangladesh. We confirmed that GR can remove chromate more efficiently than ferrihydrite with the formation of a smaller amount of sludge. Although GR is very prone to oxidation, we proved that it can actually resist to the harsh conditions of real wastewater systems and still be more efficient than ferrihydrite. Even in the presence of $265 \mathrm{mg} / \mathrm{L}$ of COD and open air atmosphere, GR could form, resist to oxidation and completely remove chromate. The XRD results of this work along with experimental evidences from literature suggest that the final solid product after $\mathrm{Cr}$ removal would be a dense sludge with good solid-liquid separability.

\section{References}

1. D. L. Bond and S. Fendorf: Environ. Sci. Technol. 37, pp. 2750-2757 (2003).

2. S. Loyaux-Lawniczak, P. Refait, J. Ehrhardt, P. Lecomte, J.M.R. Génin: Environ. Sci. Technol. 34, pp. 438-443 (2000).

3. E. Kaprara, N. Kazakis, K. Simeonidis, S. Coles, A.I. Zouboulis, P. Samaras, M. Mitrakas: J. Hazard. Mater. 281, pp. 2-11 (2015).

4. S. Asrar Ahmad and V. Un Nisa: AmericanEurasian J. Toxicol. Sci. 5, pp. 41-47 (2013).

5. T. Bolortamir and R. Egashira: J. Chem. Eng. Japan 41, pp. 1003-1009 (2008).

6. A.A. Mamun, M. Morita, M. Matsuoka, C.Tokoro: J. Hazard. Mater. 334, pp. 142-149 (2017).

7. L.H.G. Chaves: Rev. Bras. Eng. Agrícola e Ambient. 9, pp. 284-288 (2005).

8. C.P. Johnston and M. Chrysochoou: Environ. Sci. Technol. 46, pp. 5851-5858 (2012).

9. K.B. Ayala-Luis, C.B. Koch, H.C.B. Hansen: Appl. Clay Sci. 50, pp. 512-519 (2010).

10. C. Ruby, M. Abdelmoul, S. Naille, A. Renard, V. Khare, G. Ona-Nguema, G. Morin, J.M.R. Genin: Geochim. Cosmochim. Acta 74, pp. 953-966 (2010).

11. H.C.B. Hansen, S. Guldberg, M. Erbs, C. Bender Koch: Appl. Clay Sci. 18, pp. 81-91 (2001).

12. I.A.M. Ahmed, L.G. Benning, G. Kakonyi, A.D. Sumoondur, Nick J. Terrill, Samuel Shaw: Langmuir 26, pp. 6593-6603 (2010).

13. Water Environment \& APHA: Standard Methods for the Examination of Water and Wastewater Part 1000 Standard Methods for the Examination of Water and Wastewater. pp. 550 (1999).

14. C. Tokoro, S. Suzuki, D. Haraguchi, S. Izawa: Materials (Basel) 7, pp. 1084-1096 (2014).

15. C. Tokoro, T. Sakakibara, S. Suzuki: Chem. Eng. J. 279, pp. 86-92 (2015).

16. C. Tokoro, Y. Yatsugi, H. Sasaki, S. Owada: Resour. Process. 8, pp. 3-8 (2008).

17. D. Haraguchi, C. Tokoro, Y. Oda, S. Owada: J. Chem. Eng. Japan 46, pp. 173-180 (2013).

18. H.C.B. Hansen: Clay Miner. 24, pp. 663-669 (1989).

19. M.M. Kabir, A.N.M. Fakhruddin, M.A.Z. Chowdhury, Z. Fardous, R. Islam: Pollution 3, pp. 395-406 (2017).

20. R. Guilbaud, M.L.White, S.W. Poulton: Geochim. Cosmochim. Acta 108, pp. 141-153 (2013).

21. B.C. Christiansen, K. Dideriksen, A. Katz, S. Nedel, N. Bovet, H.O. Sørensen, C. Frandsen, C. Gundlach, M.P. Andersson, S.L.S. Stipp: Inorg. Chem. 53, pp. 8887-8894 (2014).

22. P. Refait, A. Géhin, M. Abdelmoula, J.M.R. Génin: Corros. Sci. 45, pp. 659-676 (2003). 